\title{
Parameters based on X-ray images to assess the physical and physiological quality of Leucaena leucocephala seeds
}

\section{Parâmetros baseados em imagens de raios x para avaliar a qualidade física e fisiológica de sementes de Leucaena leucocephala}

\author{
André Dantas de Medeiros ${ }^{1 *}$, Joyce de Oliveira Araújo1', Manuel Jesús Zavala León ${ }^{2}$, \\ Laércio Junio da Silva ${ }^{1}$, Denise Cunha Fernandes dos Santos Dias ${ }^{1}$
}

1Universidade Federal de Viçosa/UFV, Departamento de Fitotecnia, Viçosa, MG, Brasil

${ }^{2}$ Instituto Nacional de Investigaciones Forestales, Agrícolas y Pecuarias/INIFAP, Ciudad de México, México

${ }^{*}$ Corresponding author: medeiros.seeds@gmail.com

Received in September 4, 2018 and approved in November 17, 2018

\begin{abstract}
Non-destructive and high performance analyses are highly desirable and important for assessing the quality of forest seeds. The aim of this study was to relate parameters obtained from semi-automated analysis of radiographs of Leucaena leucocephala seeds to their physiological potential by means of multivariate analysis. To do so, seeds from five lots collected from parent trees from the region of Viçosa, MG, Brazil, were used. The study was carried out through analysis of radiographic images of seeds, from which the percentage of damaged seeds (predation and fungi), and measurements of area, perimeter, circularity, relative density, and integrated density of the seeds were obtained. After the X-ray test, the seeds were tested for germination in order to assess variables related to seed physiological quality. Multivariate statistics were applied to the data generated, with use of principal component analysis (PCA). X-ray testing allowed visualization of details of the internal structure of seeds and differences regarding density of seed tissues. Semi-automated analysis of radiographic images of Leucaena leucocephala seeds provides information on seed physical characteristics and generates parameters related to seed physiological quality in a simple, fast, and inexpensive manner.
\end{abstract}

Index terms: Forest species; image analysis; multivariate analysis; relative density; seed radiography.

\section{RESUMO}

Análises não destrutivas e de alta performance são altamente desejáveis e importantes para a avaliação da qualidade de sementes florestais. O objetivo deste trabalho foi relacionar parâmetros obtidos a partir da análise semi-automatizada de radiografias de sementes de Leucaena leucocephala ao seu potencial fisiológico, por meio de análise multivariada. Para tanto, foram utilizadas sementes de cinco lotes colhidos de árvores-matrizes localizadas na região de Viçosa, MG. O estudo foi realizado por meio da análise de imagens radiográficas das sementes, para as quais foram obtidos o percentual de sementes com danos (predação e fungos), e medidas de área, perímetro, circularidade, densidade relativa e densidade integrada das sementes. Após o teste de raios $X$, as sementes foram submetidas ao teste de germinação, no qual foram avaliadas variáveis relacionadas à qualidade fisiológica das sementes. Foi aplicada estatística multivariada nos dados gerados, com uso da análise de componentes principais (PCA). Por meio do teste de raios X foi possível visualizar com detalhes as estruturas internas das sementes e observar diferenças quanto à densidade de seus tecidos. Conclui-se que a análise semi-automatizada de imagens radiográficas das sementes de Leucaena leucocephala permite, de forma simples, rápida e barata, obter informações sobre características físicas e gerar parâmetros relacionados com a qualidade fisiológica.

Termos para indexação: Espécie florestal; análise de imagens; análise multivariada; densidade relativa; radiografia de sementes.

\section{INTRODUCTION}

Leucaena leucocephala (Lam.) de Wit, a leguminous tree with wide distribution in various countries, including Brazil, has been indicated as a species appropriate for composing reforestation systems in degraded areas (Bichoff et al., 2018). It makes an ecologically important contribution by improving the soil, fixing nitrogen, and controlling erosion in arid regions (Yige et al., 2012).
L. leucocephala is propagated sexually (Costa; Durigan, 2010). Thus, physiological quality is important for obtaining vigorous and uniform seedlings. However, the seeds of this species have low percentage and uniformity of germination, due to dormancy caused by the impermeability of the seed coat to water.

For assessment of the physiological quality of these seeds in the laboratory, they generally need to be scarified to obtain the maximum percentage of germination and 
for the germination process not to be slow and uneven. Nevertheless, the germination test is not only destructive, but often does not allow identification of possible damages in the seeds that compromise their physiological quality. Therefore, inclusion of non-destructive and high performance analyses for assessing seed quality is highly desirable and important for seed production programs for this species in particular. Among the techniques that meet this requirement is X-ray image analysis.

The X-ray technique indicates the radiodensity of the tissues, i.e., the mean absorption of X-rays by the tissues reflected in the image in tones of gray. Studies that use the X-ray technique with seeds of forest species generally examine variables such as percentage of occupied space in the internal cavity of the seed (Noronha; Medeiros; Pereira, 2018; Silva at al., 2013), size of the embryo (Marchi; Gomes Junior, 2017), and identification of full seeds and of embryonic abnormalities (Gomes et al., 2014) because they are associated with the physical and physiological quality of the seeds. Nevertheless, when these variables are obtained manually, the process is very slow and may generate errors in readings, especially because of the subjective interpretations made by the analysts. Automation of these determinations becomes extremely necessary to enhance this technique (Abud; Cicero; Gomes Junior, 2018), making it possible to increase the ease and speed of phenotypic analysis and to obtain information with a high level of reliability and repeatability.

Open source software, such as Image $J^{\circledR}$ (US National Institutes of Health; at http://imagej.nih.gov/ij/ download.html), can be used for this purpose. Image $J^{\circledR}$ is a pioneer software as an open tool for analysis of scientific images (Schneider; Rasband; Eliceiri, 2012) and has recently shown potential for application in analysis of radiographic images of seeds of Acca sellowiana O. Berg (Silva et al., 2013), Moringa oleifera Lam. (Noronha; Medeiros; Pereira, 2018), and Brassica oleraceae L. (Abud; Cicero; Gomes Junior, 2018). The software allows quantification of empty areas and filled areas, measurements of shape and texture, and determination of pixel density in radiographic images, physical parameters that may be related to the physiological quality of seeds.

Furthermore, studies involving integration of data from different sources require differentiated statistical interpretation, with the use of appropriate statistical models that consider the complexity of the variables involved. Thus, principal component analysis (PCA), which is a multivariate technique, becomes an alternative for extracting important information from a database by means of combined representations of new orthogonal variables, in which patterns of similarity of the observations and of the variables are exhibited as points on maps (Abdi; Williams, 2010). These associations can be made to estimate the quality of seeds through projections, facilitating understanding and interpretation of the results (Abud; Cicero; Gomes Junior, 2018).

Thus, integration between semi-automated analysis of X-ray images along with acquisition of new parameters associated with physical characteristics and with the physiological quality of $L$. leucocephala seeds through the multivariate technique of principal components could constitute a practical and efficient method for interpreting the information obtained from images. In addition, the physiological quality of the seeds could be estimated rapidly, regardless of the occurrence and of the degree of dormancy of the seeds of the lots assessed.

Understanding the relevance of inclusion of innovative methodologies, the aim of this study was to relate parameters obtained from semi-automated analysis of radiographs of Leucaena leucocephala seeds to their physiological potential through multivariate analysis.

\section{MATERIAL AND METHODS}

Seeds were collected on the campus of the Universidade Federal de Viçosa (2046'03.0”S 42 $\left.52^{\prime} 15.4^{\prime \prime} \mathrm{W}\right)$ in the municipality of Viçosa, Minas Gerais, Brazil, in February 2018, from five adult parents trees of Leucaena leucocephala, constituting five seed lots.

First, the moisture content of the seeds from each lot was determined by the laboratory oven method $\left(105 \pm 3^{\circ} \mathrm{C}\right.$, for 24 hours), based on the Regras para Análises de Sementes [Rules for Seed Analysis] (Brasil, 2009); 2 replications of 20 seeds for each lot were used for this purpose.

Four replications of 50 seeds of each lot were used for analyses of the internal morphology of the seeds. The seeds were fixed in an ordered way on transparency paper with double-sided tape to allow later individual identification in subsequent analyses. After that, radiographic images were generated using the Faxiton MX-20 (Faxitron X-ray Corp. Wheeling, IL, U.S.A.) device; seeds were subjected to radiation for 10 seconds at $32 \mathrm{kV}$ and a focal distance of $30 \mathrm{~cm}$. The digital images generated were stored in a computer and used for visual assessment of the percentage of seeds damaged by insects and fungi and seeds free of damage.

The images were also analyzed in a semi-automated manner by the Image $J^{\circledR}$ software to obtain the variables described below. Relative density (Geiger; Blem; Ludwig, 2016) is defined as the sum of the gray values of all the pixels in the area selected, divided by the number of pixels 
of the selection. Integrated density is the sum of the values of the pixels in the image or selection, which is equivalent to the product of area and the mean gray value (relative density). The area is the area of selection obtained in square pixels and later converted to units of square millimeters $\left(\mathrm{mm}^{2}\right)$. Perimeter is the length of the external limit of the selection. Circularity is obtained through the equation

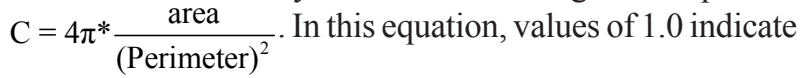
a perfect circle, and an elongated form is suggested to the extent that values tend to 0 .

After the X-ray test was performed, the seeds were manually scarified by sufficiently scraping them at the tip opposite the embryonic axis to allow water to enter the seed. After that, the germination test was conducted in rolls of germination paper moistened with water in the amount of 2.5 times the weight of the dry paper, which were then kept in a germinator at a constant temperature of $25^{\circ} \mathrm{C}$ (Brasil, 2009). Four replications of 50 seeds were sown in the germination paper, maintaining the seed arrangement originally used in the X-ray test. Final germination count was made at 10 days after sowing (Brasil, 2009), at which time the percentage of germinated seeds was obtained (radicle emergence $>5 \mathrm{~mm}$ ).

Seedling length was obtained with the aid of a millimeter ruler. Data on the length of the root, hypocotyl, and whole seedling were expressed in millimeters per seedling. The results were interpreted using parallel analysis of radiographic images of seeds and values of their respective seedlings.

The relative density of seeds was classified according to the normal distribution frequency of the values obtained for the seeds of each lot in order to correlate the morphological characteristics obtained from the radiographic images and the performance of the seedlings, and allow inferences to be made regarding seed vigor. Five categories of seeds were adopted based on the frequency distribution of relative density as follows: Category 1 - seed density less than 136.6; Category 2 - seed density from 136.7 to 154.2 ; Category 3 - seed density from 154.3 to 171.7 ; Category 4 - seed density from 171.8 to 189.2 ; Category 5 - seed density greater than 189.3 .

The experiment was conducted in a completely randomized experimental design. Multivariate statistics using principal component analysis (PCA) were applied for data analysis. The mean values obtained for each seed lot were calculated and normalized in advance. An " $\mathrm{x}$ p" matrix was obtained, where " $n$ " is the number of categories $(n=5)$ and " $p$ " is the number of variables analyzed $(p=11)$. Eigenvalues and eigenvectors were calculated from the covariance matrixes and plotted on two-dimensional graphs (circle of eigenvectors of the variables and the diagram of ordering of categories) generated using the factoextra packages (Kassambara; Mundt, 2015). The Pearson simple correlation coefficients (r) were also calculated for all the combinations among the seed physiological and physical quality assessment tests in which the significance of the r values was determined by the test $(p \leq 0.05)$. The $\mathrm{R}$ statistical software was used for analyses (R Core Team, 2017).

\section{RESULTS AND DISCUSSION}

The moisture content of the L. leucocephala seeds showed low variation among the lots assessed $(8.1 \%$ to $8.8 \%$ ) and allowed good visualization of the internal morphology of the seeds (Figure 1). According to Simak (1991), seed moisture content is one of the factors that affect the optical density of the radiograph, such that the greater the seed moisture content is, the lower the absorption of radiation by the tissue will be, resulting in opaque images. Therefore, low moisture content of the seeds used in the X-ray test is important to obtain radiographs with greater detailing of the internal structures of the seed. In studies conducted with X-ray analysis of seeds of Moquiniastrum polymorphum (Faria et al., 2018), Anacardium othonianum (Silva et al., 2017), Senna multijuga (Marchi; Gomes Junior, 2017), Terminalia argentea (Gomes et al., 2014), and Crotalaria juncea (Arruda et al., 2016), it was possible to visualize seed parts with moisture contents from $8 \%$ to $12 \%$.

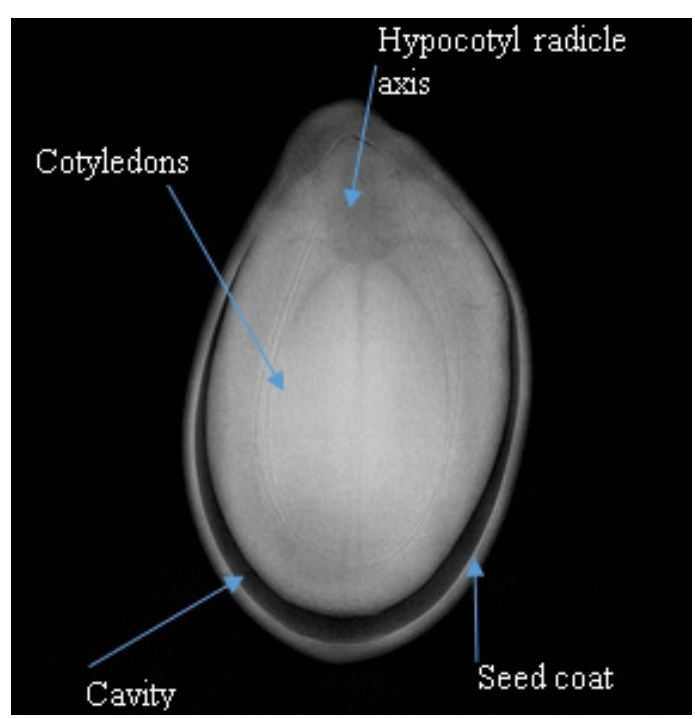

Figure 1: Radiographic image of an L. leucocephala seed with indications of its internal structures. 
Other factors related to seed constitution may also affect the detailing of internal structures on the radiograph that is generated (Arruda et al., 2016). Nogueira Filho et al. (2017) observed that the X-ray test did not allow determination of the level of development of the internal structures of sesame seeds, due to the impossibility of visualizing these structures, which resulted from the high oil concentration in sesame seeds, typical of oilseed plants. In this respect, the low oil concentration in $L$. leucocephala seeds, around 5.44\% (Nehdi et al., 2014), may have contributed to allow visualization of the internal structures of the seeds.

The germination percentage of seeds of all the lots assessed was higher than the minimum value $(65 \%)$ established for sale of seeds of this species in Brazil (Brasil, 2008), indicating high viability of the seed lots (Figure 2). Nevertheless, differences in germination among the lots are observed, notably the superiority of the seeds of Lots 1 and 2 and the inferiority of the seeds of Lot 3.

The relative densities of the L. leucocephala seeds differed among the 5 lots, and there was greater variability in the values obtained for Lots 3, 4, and 5 (Figure 2). The relative density of the seed is related to radiolucency (dark) and radiopacity (light) levels, translated to the image in gray values, which is a fast, easy, and inexpensive parameter for making measurements. According to Huang et al. (2015), these characteristics are important for ensuring quality seeds during sowing for farmers and the industry. According to Abud, Cicero and Gomes Junior (2018), this parameter allows inferences to be made concerning the density of internal seed tissues and, therefore, concerning seed physiological quality.

Principal component analysis allowed determination of the contribution of each variable obtained from X-ray images and from assessments of germination and seedling length for the individual components, which was used to fit the models to the first two components, and it also allowed discrimination of the different categories of relative density of the seeds (Figure 3 ). The categories of the L. leucocephala seeds obtained an eigenvalue of 7.94 in the first component (PC1), which explained $72 \%$ of the total variability of the data. The second component had an eigenvalue of 2.32, which represented $21 \%$ of the total variability of the data. The sum of the first two principal components encompassed $93.38 \%$ of the total original variability, a value greater than the minimum (80\%) proposed by Jolliffe (2011) to have an effective explanation of the total sample variance; therefore, the other components obtained were not considered.

Principal component 1 (PC1) was composed of the linear sum of the results of hypocotyl, root, and seedling length, relative density, integrated density, perimeter, germination, and damage by fungi, with subtraction of results of circularity, area, and damage by insects (Figure 2), according to the following model:

PC1 $=0.98 *$ (hypocotyl length $)+0.99 *$ (root length $)+$ $0.99 *$ (seedling length) $+0.97 *$ (relative density) +0.94 $*$ (perimeter $)+0.98 *$ (germination $)+0.98 *$ (integrated density) $+0.40 *$ (damage by fungi) $-0.86 *$ (circularity) $-0.39 *$ (damage by insects) $-0.41 *$ (area)

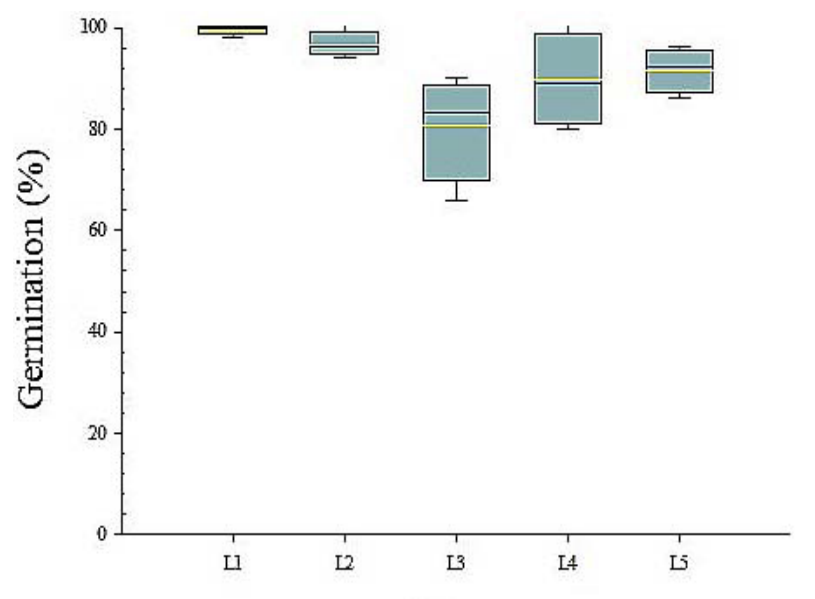

Lots

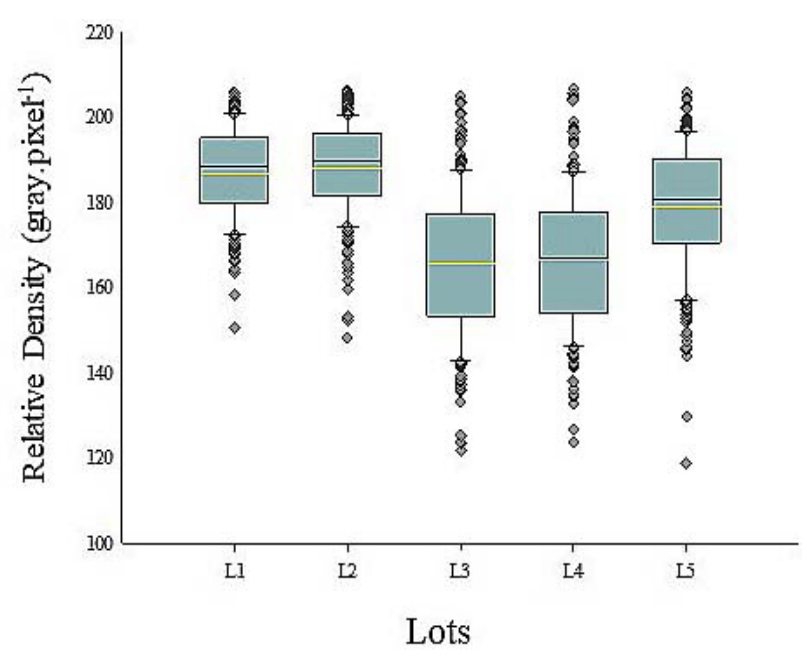

Figure 2: Germination and relative density of five lots of $L$. leucocephala seeds obtained by means of the Image ${ }^{\circledR}$ software. 

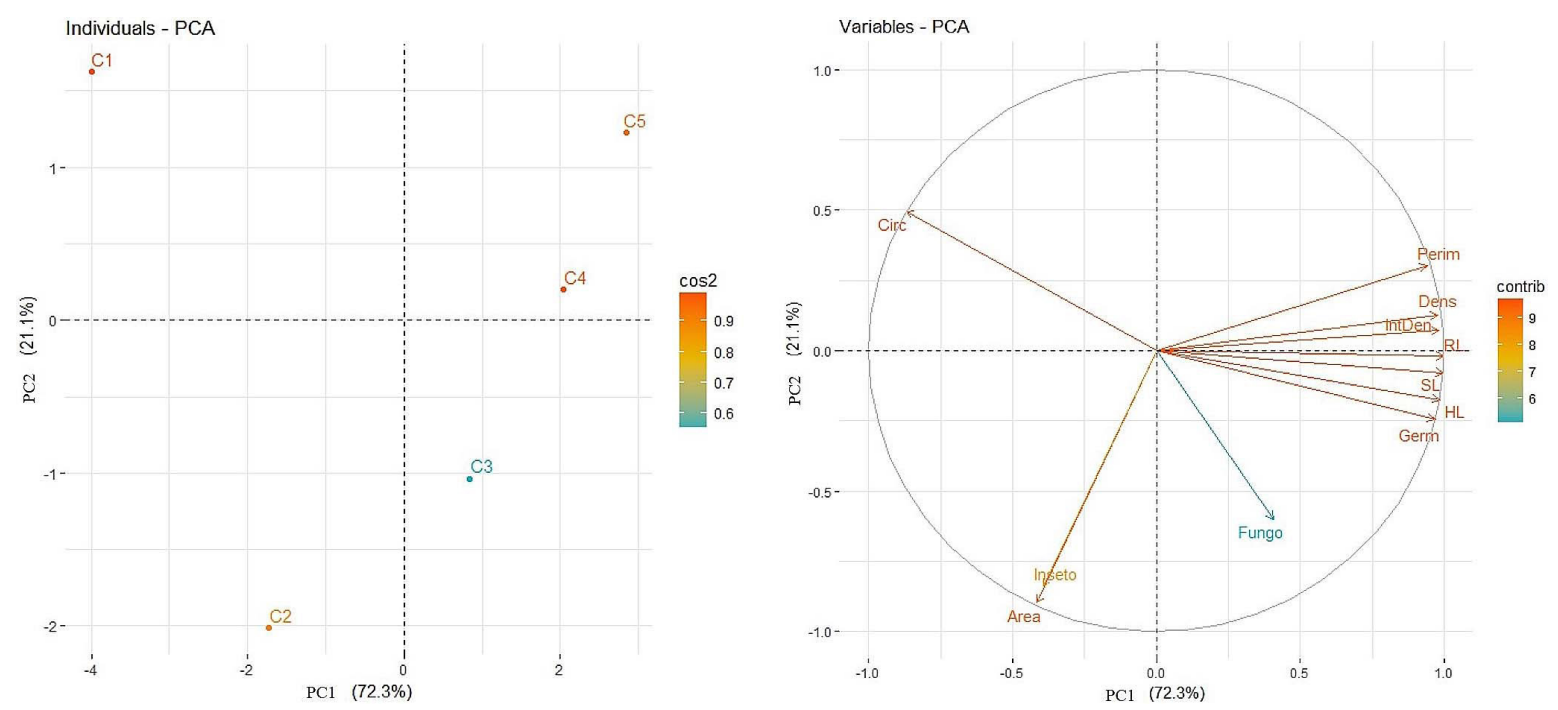

Figure 3: Biplot obtained by clustering of the variables related to the seed and seedling characteristics, classified in different categories for seed lots of Leucaena leucocephala. PC1 - Principal Component 1; PC2 - Principal Component 2; Circ - circularity; HL - hypocotyl length; RL - radicle length; SL - seedling length; Dens - relative density; Area; Perim - perimeter; IntDes - integrated density; Fungo - damage from fungi; Inseto - damage from insects; Germ - germination; C1 - Category 1; C2 - Category 2; C3 - Category 3; C4 - Category 4; C5 - Category 5.

The variables exhibited different weights in the calculation of $\mathrm{PC} 1$ so that variables such as area, damage by fungi, and damage by insects have little effect on the component, i.e., the coefficients were negative and lower than 0.42 . Thus, the seeds of Category 4 and 5 exhibited higher values for lengths of hypocotyl, root, and seedling, relative density, integrated density, perimeter, and germination, and the lower values for circularity and damage by insects, as can be observed in Figure 3. Category 3 exhibited an intermediate position on the $\mathrm{PC} 1$ axis $(0.84)$, and categories 1 and 2 exhibited lower values for $\mathrm{PC} 1,-3.98$ and -1.72 , respectively, which indicates, in general, that the seeds of these categories had low performance in relation to the physiological variables analyzed.

The mathematical model obtained for Principal Component 2 (PC2) was:

PC2 $=-0.17 *$ (hypocotyl length) $-0.02 *$ (root length) $0.07 *$ (seedling length) $+0.12 *$ (relative density) +0.30 $*$ (perimeter) $-0.24 *$ (germination) $+0.07 *$ (integrated density) $-0.60 *$ (damage by fungi) $+0.49 *$ (circularity) -0.83 $*$ (damage by insects) $-0.89 *$ (area)

The most important variable in the calculation of $\mathrm{PC} 2$ was the area (coefficient 0.84 ), followed by damage by insects (coefficient 0.83 ). According to the model proposed, the seeds of Categories 1 and 2 exhibited the greatest circularity and area, respectively, and the seeds of Category 3 were those that exhibited the highest levels of damage provoked by fungi. In addition, the seeds of Category 2 exhibited the greatest number of seeds with signs of damage by insects, and this variable is strongly correlated with the area of the seeds (Figure 3). Therefore, it can be inferred that seeds with a greater area are more subject to predation by insects, and that the most vigorous seeds exhibited more elongated shapes, providing lower circularity, greater perimeter, greater density, and more vigorous plants (Figure 3).

According to Abud, Cicero and Gomes Junior (2018), an estimate of seed quality can be generated by principal component analysis through projections and associations among categories and variables, facilitating understanding and interpretation of the results. Thus, the closer the variable is to the circle of correlations, the greater the possibility of reconstructing this variable from the first two components will be. In contrast, the closer to the center of the plot a variable is, the less important it will be for the components (Abdi; Williams, 2010).

In the correlation matrix (Figure 4), positive correlations are observed among the data obtained for germination, lengths of hypocotyl, radicle, and seedling, and the variables of relative density, integrated density, and perimeter $(>87 \%)$. In contrast, circularity exhibited negative and high correlations with the variables of seedling length and seed density $(<-0.80)$. 


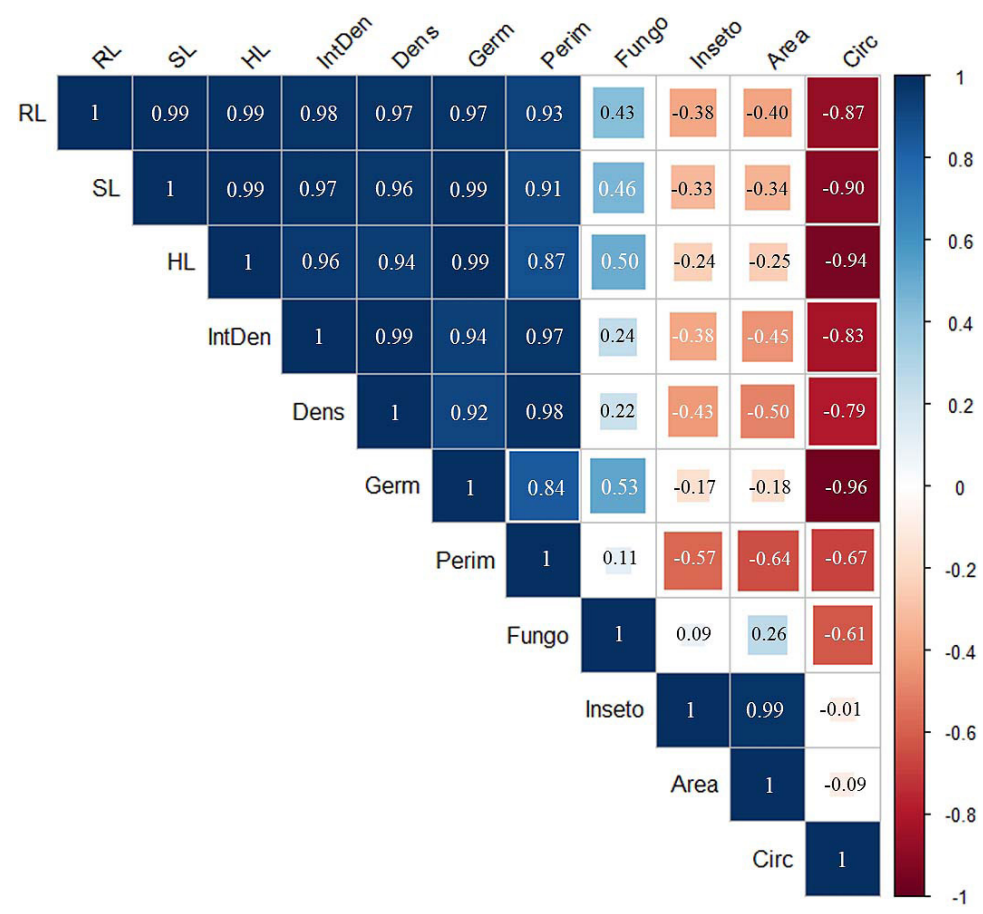

Figure 4: Correlation matrix obtained from data of X-ray images of seeds and seedling characteristics of Leucaena leucocephala. RL - radicle length; SL - seedling length; IntDes - integrated density; Dens - relative density; Germ germination; HL - hypocotyl length; Perim - perimeter; Fungo - damage by fungi; Inseto - damage by insects; Area; Circ - circularity.

High correlation between seedling length and relative density of seeds is necessary for the purpose of validation of the method of X-ray image analysis to assess seed quality (Abud; Cicero; Gomes Junior, 2018). The correlations obtained for the data of relative density with the data of length in this study (Figure 4) indicate that the use of this parameter is efficient for estimating the performance of $L$. leucocephala seedlings.

The descriptive features related to shape of the seeds, such as perimeter and circularity, were also efficient indicators of seedling performance, such that the greater the perimeter and the lower the circularity, the greater seedling performance was (Figure 3). In addition, the close relationship between seed area and damage by insects $(0.99)$ is an indication that larger seeds could be easier targets of predation by insects (Figure 4). Nevertheless, in this study, a low correlation was observed between germination (radicle emergence) and damage by insects $(-0.17)$ within the categories. Damage by predation was probably more frequent in the cotyledonary regions and did not reach the embryonic axis, and thus, the germination process could occur. In contrast, Javorski and Cicero (2017) show that damage caused by insects observed by the X-ray test in sorghum seeds was closely related to losses caused to germination in seed lots, since the damage compromised a considerable part of the seeds, including vital regions such as the embryonic axis, resulting in seed death.

Application of the X-ray test in seeds of forest species such as Moringa oleifera (Noronha; Medeiros; Pereira, 2018), Senna multijuga (Marchi; Gomes Junior, 2017), and Terminalia argentea (Gomes et al., 2014) also showed a relationship between the internal morphology of the seeds and their physiological quality. However, other parameters of assessment were used to characterize the internal morphology of the seeds, such as identification of full seeds and malformed seeds, damage by insect predation, percentage of empty internal area, and embryo size.

Recently, Silva et al. (2017) showed that the use of the X-ray technique is advantageous in reducing storage costs of seeds and for seedling production programs of Anacardium othonianum Rizz, a native Brazilian species, through making it possible to separate empty achenes or achenes with embryonic abnormalities, contributing to the formation of lots with more vigorous seeds. 
Nevertheless, it is important to highlight that various aspects, such as the internal cavity occupied by the embryo, the presence of mechanical damage, spots that indicate tissue deterioration, or seed malformations that should be considered in this type of study (Marchi; Gomes Junior, 2017), can be assessed in an indirect manner by means of analysis of relative density since deterioration, mechanical damage, and lower embryo filling make for a higher level of radiolucency (dark), reducing the gray value and, consequently, relative density. In this respect, seeds with higher values of relative density tend to exhibit better physiological quality.

Lots 1 and 2 exhibited a lower proportion of seeds in the first three categories ( $8.5 \%$ and $7 \%$ ) and concentrated most of their seeds in Categories 4 and 5 (91.5\% and 93\%, respectively) (Table 1). Categories 4 and 5 were those that most correlated with the highest values of seedling length (Figure 3). Lots 3 and 4 exhibited more than half of their seeds in the first three categories and a lower quantity of seeds in Categories 4 and 5 (Table 1). This is an undesirable characteristic, since the first three categories had a greater relationship with damage by insects and by fungi, and the seeds in this category are considered less vigorous. Lot 5 appeared as a lot of intermediate physiological quality; however, most of its seeds $(74.5 \%)$ were classified in Categories 4 and 5.

Table 1: Proportion of L. leucocephala seeds belonging to different categories with differences in regard to seed physiological quality.

\begin{tabular}{crrrrr}
\hline \multirow{2}{*}{ Category } & \multicolumn{5}{c}{$\%$} \\
\cline { 2 - 6 } & Lot 1 & Lot 2 & Lot 3 & Lot 4 & Lot 5 \\
\hline C1 & 0 & 0 & 4 & 3 & 1 \\
C2 & 0.5 & 1.5 & 22.5 & 21 & 5.5 \\
C3 & 8 & 5.5 & 35 & 33.5 & 19 \\
C4 & 46 & 40 & 30 & 35 & 47.5 \\
C5 & 45.5 & 53 & 8.5 & 7.5 & 27 \\
\hline
\end{tabular}

Detailing the percentage of seeds within each category in the lot may be relevant from the practical point of view since lots with a higher percentage of seeds classified in the first categories $(1,2$, and 3$)$ represent seed lots with lower vigor. A greater number of seeds allocated in categories of greater relative density indicates seed lots with higher physiological quality. Abud, Cicero and Gomes Junior. (2018) also found that seed lots that had a greater number of seeds in classes of low relative density exhibited lower seedling lengths, a reflection of lower seed vigor.
The use of parameters such as relative density, integrated density, and descriptive features of shape associated with semi-automated tools, such as Image ${ }^{\circledR}$, effectively contributed to reduction in time of assessment of seed quality, as well as totally removed the error inherent to subjectivity of the analyst, which, according to Gomes-Junior (2010), is a current concern of research for the purpose of establishing greater reliability of the results obtained. Studies performed on Moringa oleifera (Noronha; Medeiros; Pereira, 2018) and Acca sellowiana (Silva et al., 2013) showed the potential of the Image $\mathrm{J}^{\circledR}$ software in evaluation of radiographs directed to determination of empty and filled areas of the internal cavity of the seed, relating them to seed physiological quality. Prado-Alves et al. (2018) also indicated Image $J^{\circledR}$ as a good alternative in aiding identification of differences in physiological potential of seed lots of scarlet eggplant (Solanum gilo) in different stages of maturity.

Figure 5 shows the radiographic images of $L$. leucocephala seeds of each category with their respective histograms of relative density adopted in this study, and their seedlings at five days after sowing. Differences among categories can be identified in relation to the radiographic images of the seeds, with radiopacity decreasing from the fifth category to the first. This difference in the value of the images in relative density can be attributed to the differences in the degree of deterioration of the seeds of the same lot, in which the lower values of relative density indicate less dense tissues and therefore low physiological quality.

In squash seeds, Antônio et al. (2016) found a close relationship between biochemical assessments and assessments with the X-ray test, noting that expression of the enzymes catalase and superoxide dismutase, both related to the antioxidant system, is directly related to seed quality, and by means of them, it is possible to separate the lots in the same classes established by the $\mathrm{X}$-ray test. Thus, non-destructive techniques prove to be fast, accurate, reliable, and simple tools, ready for use in classification of quality, detection of damage, detection of insect infestation, and prediction of germinability in seeds (Rahman; Cho, 2016).

In light of the above, integration between semiautomated analysis of X-ray images and acquisition of new parameters associated with physical characteristics and physiological quality of L. leucocephala seeds proves to be a practical and efficient method for quickly estimating the physiological quality of seeds, regardless of the occurrence and the degree of dormancy of the seeds in the lots assessed. 
C5
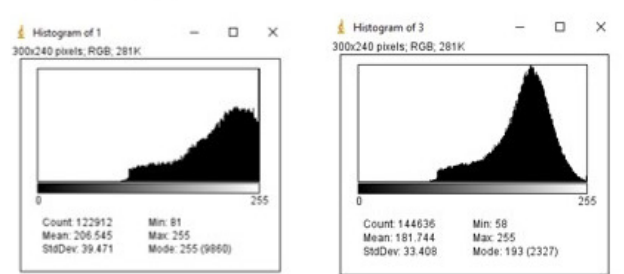

C4

C3

$\mathrm{C} 2$

C1
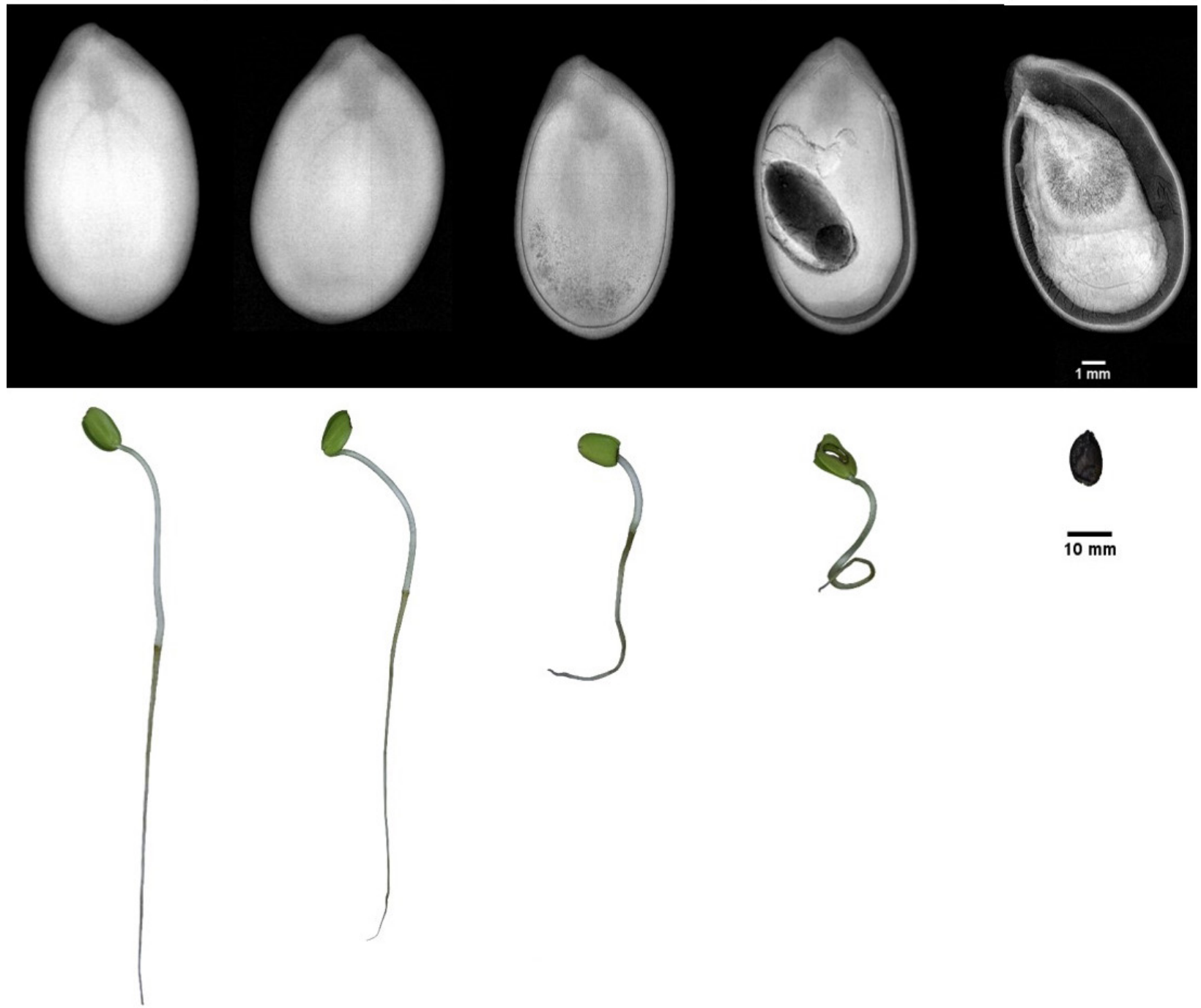

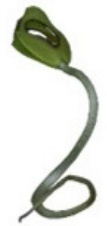

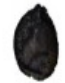

$\overline{10 \mathrm{~mm}}$

Figure 5: Radiographic images of Leucaena leucocephala seeds of each category with their respective histograms of relative density and seedlings at 5 days after sowing.

\section{CONCLUSIONS}

The X-ray test is efficient in assessing the internal morphology of Leucaena leucocephala seeds. Semiautomated analysis of radiographic images allows information to be extracted regarding physical characteristics of the seeds and creation of parameters related to seed physiological quality in a simple, fast, and inexpensive manner. Multivariate statistics with principal component analysis can be used in interpretation of variables related to seed quality. 


\section{ACKNOWLEDGEMENTS}

The authors are grateful to the Departments of Fitotecnia and Entomologia (UFV, Viçosa, Brazil) for the experimental installations and to Dr. Paulo Cesar Hilst for the contribution in obtaining the images used in the work. This study was financed in part by the Coordenação de Aperfeiçoamento de Pessoal de Nível Superior - Brasil (CAPES) - Finance Code 001.

\section{REFERENCES}

ABDI, H.; WILLIAMS, L. J. Principal component analysis. Wiley Interdisciplinary Reviews: Computational Statistics, 2(4):433-459, 2010.

ABUD, H. F.; CICERO, S. M.; GOMES JUNIOR, F. G. Radiographic images and relationship of the internal morphology and physiological potential of broccoli seeds. Acta Scientiarum: Agronomy, 40(1):1-9, 2018.

ANTÔNIO, L. N. et al. Efficiency of $x$ - ray test in the identification of damage and its relation with the pumpkin seeds quality. International Journal of Current Research, 8(2):2647126475, 2016.

ARRUDA, N. et al. Radiographic analysis to assess the seed structure of Crotalaria juncea L. Journal of Seed Science, 38(2):161-168, 2016.

BICHOFF, R. S. et al. Overcoming seed dormancy and evaluation of viability in Leucaena leucocephala. Australian Journal of Crop Science, 12(1):168-172, 2018.

BRASIL. Ministério da Agricultura, Pecuária e Abastecimento. Normas e padrões para comercialização de sementes de espécies forrageiras de clima tropical. Brasília, DF: Diário Oficial da República Federativa do Brasil, 2008.

BRASIL. Ministério da Agricultura, Pecuária e Abastecimento Regras para análise de sementes. Brasília: MAPA/ACS, 2009. 395p.

COSTA, J. N. M. N.; DURIGAN, G. Leucaena leucocephala (Lam.) de Wit (Fabaceae): Invasora ou ruderal? Revista Árvore, 34(5):825-833, 2010.

FARIA, J. C. T. et al. Physical quality of seeds of Moquiniastrum polymorphum. Brazilian Journal of Biology, 6984:1-7, 2018.

GEIGER, M.; BLEM, G.; LUDWIG, A. Evaluation of ImageJ for relative bone density measurement and clinical application. Journal of Oral Health and Craniofacial Science, 1(1):1221, 2016.
GOMES, K. B. P. et al. Avaliação da morfologia interna de sementes de Terminalia argentea (Combretaceae) pelo teste de raios $\mathrm{X}$. Revista Ciência Agronômica, 45(4):752-759, 2014.

GOMES-JUNIOR, F. G. Aplicação da análise de imagens para avaliação da morfologia interna de sementes. Informativo Abrates, 20:33-51, 2010.

HUANG, M. et al. Review of seed quality and safety tests using optical sensing technologies. Seed Science and Technology, 43(3):337-366, 2015.

JAVORSKI, M.; CICERO, S. M. Utilização do teste de raios X na avaliação da qualidade de sementes de sorgo. Revista Brasileira de Milho e Sorgo, 16(2):310-318, 2017.

JOLLIFFE, I. Principal Component Analysis. In: LOVRIC, M. (Ed.). International Encyclopedia of Statistical Science. Berlin, Heidelberg: Springer Berlin Heidelberg, 2011. p.1094-1096.

KASSAMBARA, A.; MUNDT, F. Factoextra: Extract and visualize the results of multivariate data analysis. $R$ package version 1.0. 3., 2015.

MARCHI, J. L. DE; GOMES JUNIOR, F. G. Use of image analysis techniques to determine the embryo size of Senna multijuga (Rich.) seeds and its relation to germination and vigor. Journal of Seed Science, 39(1):13-19, 2017.

NEHDI, I. A. et al. Leucaena leucocephala (Lam.) de Wit seed oil: Characterization and uses. Industrial Crops and Products, 52:582-587, 2014.

NOGUEIRA FILHO, F.P. et al. Effectivity of X-ray test to evaluate the physiological quality of sesame seeds due to fruits position at the plant. Revista Brasileira de Ciências Agrárias, 12(4):435-440, 2017.

NORONHA, B. G.; MEDEIROS, A. D.; PEREIRA, M. D. Avaliação da qualidade fisiológica de sementes de Moringa oleifera Lam. Ciência Florestal, 28(1):393, 2018.

PRADO-ALVES, M. V. et al. Image analysis, quality and maturation of jiló (Solanum gilo) seeds. Agrociencia, 52:267-278, 2018.

R CORE TEAM. R Development Core TeamR: A Language and Environment for Statistical Computing, 2017. Available in: $<$ https://www.r-project.org/>

RAHMAN, A.; CHO, B. K. Assessment of seed quality using non-destructive measurement techniques: A review. Seed Science Research, 26(04):285-305, 2016.

SCHNEIDER, C. A.; RASBAND, W. S.; ELICEIRI, K. W. NIH Image to Image): 25 years of image analysis. Nature Methods, 9(7):671-675, 2012. 
SILVA, L. A. et al. Radiographic image analysis of Anacardium othonianum Rizz (anacardiaceae) achenes subjected to desiccation. Acta Scientiarum. Agronomy, 39(2):235, 2017.

SILVA, V. N. et al. Avaliação da morfologia interna de sementes de Acca sellowiana O. Berg por meio de análise de imagens. Revista Brasileira de Fruticultura, 35(4):1158-1169, 2013.
SIMAK, M. Testing of forest tree and shrub seeds by X-radiography. In: GORDON, A. G.; GOSLING, P.; WANG, B. S. P. (Ed.) Tree and shrub seed handbook. Zurich: ISTA, 1991. p.1-28.

YIGE, C. et al. Physiological responses of Leucaena leucocephala seedlings to drought stress. Procedia Engineering, 28(2011):110-116, 2012. 